\title{
Dificultăți de traducere în limba română a Aforismelor lui Arthur Schopenhauer. $O$ analiză contrastiv-diacronică $(I)$
}

\author{
Cecilia-Iuliana Vârlan* \\ Facultatea de Litere, Universitatea „Ovidius”, Aleea Universității 1, 900472 Constanța, România
}

\section{Despre articol}

Istoric:

Primit 9 noiembrie 2015

Acceptat 19 noiembrie 2015

Publicat 12 februarie 2016

Cuvinte-cheie:

traducere

diacronie

analiză comparată

\begin{abstract}
Rezumat
Lucrarea de față se concentrează asupra unei opere de maturitate a filozofului german Arthur Schopenhauer, Aforisme asupra înțelepciunii in viață, și asupra singurei versiuni românești a acesteia, realizate de Titu Maiorescu la sfirșitul secolului al XIX-lea. Existența a cinci variante ale versiunii românești, publicate de traducătorul însuşi de-a lungul a patru decenii, reprezintă o dovadă clară a faptului că transpunerea în românește a acestui text de filozofie practică a incumbat o serie întreagă de dificultăți de traducere. Urmărind modul în care Titu Maiorescu a încercat să rezolve aceste dificultăţi, prin adoptarea anumitor soluții traductologice, am realizat o analiză a acestora, din perspectivă lingvistică, cercetarea urmînd concomitent două direcții: contrastivă (rezultată din suprapunerea textului-sursă şi a textului-țintă) și diacronică (urmărind intervențiile realizate de acelaşi traducător asupra propriului text, la intervale de timp diferite). Demersul de analiză lingvistică a traducerii unui text filozofic ni s-a părut util nu doar studiului nostru, ci și viitorilor eventuali traducători ai Aforismelor, a căror intenție ar putea fi aceea de a adapta discursul versiunii românești a lui Titu Maiorescu la limba română contemporană, ținînd seama de evoluția evidentă a acesteia și, mai ales, a componentei sale de limbaj filozofic.
\end{abstract}

\section{Introducere}

\subsection{Premise}

Prima traducere în limba română—şi singura, pînă în prezent-a lucrării Aforisme asupra ințelepciunii in viață, de Arthur Schopenhauer ${ }^{1}$, a fost realizată, către sfîrşitul secolului al XIX-lea, de junimistul Titu Maiorescu. După un secol de la publicarea variantei considerate a fi definitive de către cercetători, editurile românești continuă să publice această traducere, adaptînd-o-doar-normelor ortografice actuale. Faptul că există cîteva variante ale versiunii românești, pe care Titu Maiorescu le-a publicat în timpul vieții sale, se datorează nu doar firii sale perfecționiste, ci-mai ales-existenței unor dificultăți de traducere pe care acest text filozofic german le-a ridicat la tălmăcirea sa în limba română și pe care învățatul junimist încerca să le rezolve cu fiecare revizuire pe care o făcea textului său. Analiza pe care o propunem aici aduce în discuție respectivele dificultăți, cu scopul de a sublinia modul în care acestea au fost rezolvate (sau nu) în limba țintă (limba română), prin valorificarea resurselor de care dispune aceasta pentru a compensa lipsurile generate de imposibilitatea suprapunerii perfecte a celor două idiomuri implicate în traducere.

\subsection{Materialul de lucru}

Cercetarea noastră se întemeiază pe o analiză contrastivă a unui text-sursă și a trei ediții succesive ale textului-țintă. Materialul de lucru pentru textul-sursă este format din textul original al Aforismelor, în limba germană, inclus în ediția operelor complete ale lui Arthur Schopenhauer, realizată de Julius Frauenstädt (Frauenstädt, 1891, p. 331-530), editorul personal al filozofului german și executorul său literar. Acest text a fost coroborat cu o ediție bibliofilă a Bibliotecii Naționale a Germaniei, ediție care, conform

\footnotetext{
*Adresă de corespondență: varlan_c@yahoo.com.

${ }^{1}$ Pe întreg parcursul prezentului articol, această lucrare va fi numită Aforisme.
} 
Cecilia-Iuliana Vârlan

casetei redacționale, reproduce textul original și autorizat de însuși autorul lucrării (Haack \& Haack, 2013). Pentru textele-țintă, analiza se bazează_precum am menționat mai sus—pe trei ediții succesive ale traducerii Aforismelor în limba română, datorate lui Titu Maiorescu însuși, precum și pe reeditări moderne, care au beneficiat de îngrijiri academice (Schopenhauer, 1872, 1876-1877, 1890, 1969, 1997).

\subsection{Metoda de lucru}

Analiza contrastivă a celor două texte, original și traducere, pe de o parte, precum și studiul diferitelor variante existente ale versiunii românești, pe care traducătorul le-a realizat în momente diferite ale creaţiei sale, pe de altă parte, determină dublul caracter, contrastiv-diacronic, al cercetării de față. În consecință, principalele modalități de analiză pe care le utilizăm în analiza versiunilor românești ale traducerii în limba română a Aforismelor lui Arthur Schopenhauer sînt descrierea și analiza contrastiv-tipologică, în conformitate cu cele două direcții pe care se desfășoară cercetarea pe care ne-am propus-o. Plecînd de la textul original, vom suprapune diversele variante existente ale traducerii din opera respectivă, urmînd a analiza punctual metodele și strategiile de traducere utilizate de Titu Maiorescu, în demersul său de a realiza o traducere adecvată. Concret, vom examina asemănările și diferențele dintre diferitele opțiuni de traducere, vom identifica metodele și strategiile de traducere utilizate, analizînd validitatea și aplicabilitatea acestora, urmînd a determina gradul în care traducerea respectivă își atinge scopul, și anume acela de a reuși comunicarea în textul-țintă a sensurilor și a structurilor logice și emoționale ale textului-sursă. Astfel, vom analiza contrastiv și diacronic, totodată, intervențiile pe care traducătorul le-a realizat în propriul text, în momente diferite ale elaborării versiunii traduse. De asemenea, în anumite locuri, în care mesajul din textul-țintă pare să fie oarecum distorsionat față de original, ne-am permis să propunem soluții noi de traducere, ținînd seama de evoluția evidentă a limbii române, mai ales a componentei sale de limbaj filozofic, de la momentul realizării traducerii şi pînă în prezent.

Nivelul de analiză ales este cel al macrotextului (Ungureanu, 2011), care a presupus examinarea structurilor lexico-gramaticale, sintactice și stilistico-pragmatice ale fiecărui enunț integral dintr-un fragment ales. Scopul a fost acela de a observa cum funcționează mecanismele semantico-stilistice la nivelul respectiv și cum au fost acestea transferate în textul-țintă. Pentru exemplificare, am ales primul capitol al Aforismelor, intitulat Introducere, în care Arthur Schopenhauer definește obiectul de studiu și metoda investigației sale filozofice, delimitîndu-le de interesele sale anterioare în acest domeniu.

\section{Contextul apariției Aforismelor în cultura română}

Exegeții operei schopenhaueriene au descris cele două volume ale lucrării Parerga und Paralipomena ${ }^{2}$, în care sînt integrate aceste Aforisme, ca fiind o „culegere de fragmente, de schițe și de eseuri dintre care unele nu au decît un raport destul de indirect cu filozofia sa" (Ribot, 1993, p. 13). Autorul însuși le considera doar niște "gînduri singulare, însă ordonate sistematic" (apud Safranski, 1998, p. 348). În mod ironic, însă, tocmai aceste gînduri au fost cele care i-au facilitat consacrarea în lumea filozofică a vremii sale, în timp ce opera sa principală, Lumea ca voință și reprezentare, o lucrare de tinerețe, publicată la Leipzig, în 1819, într-un singur volum, a trecut neobservată, deși A. Schopenhauer își expusese aici, deja, întregul său sistemul filozofic. Cel de-al doilea volum al acestui opus magnum, adăugat de către autor cu prilejul publicării celei de-a doua ediții, în 1844, împreună cu toate celelalte lucrări ale sale sînt considerate a fi doar extensii explicative ale doctrinei sale filozofice expuse în acel prim volum (Ribot, 1993, p. 13).

Precum am amintit mai sus, renumele și consacrarea ca filozof universal recunoscut au sosit abia către sfîrșitul vieții sale, odată cu apariția celor două volume intitulate Parerga und Paralipomena. Considerată ca fiind o adevărată „filozofie pentru societate” (Schopenhauer, 1978, p. 244; apud Safranski, 1998, p. 348), lucrarea a produs un real ecou în epocă, reușind să stîrnească interesul cititorilor săi. Cele care au devenit celebre mai tîrziu au fost tocmai Aforismele, incluse în volumul întîi al lucrării menționate. Succesul de care s-au bucurat acestea în rîndul cititorilor a declanșat plasarea autorului lor în centrul interesului

\footnotetext{
${ }^{2}$ Această lucrare a fost publicată pentru prima dată, în două volume, la Berlin, în 1851 .
} 
față de filozofie al vremii. Cauzele acestui succes, cercetate de exegeții operei pesimistului german, rezidă în adoptarea unui ton sfătos și în renunțarea relativă la pesimismul fundamental al doctrinei sale, pe care A. Schopenhauer îl afirmase, cu deosebită forță, în toate scrierile sale precedente și, mai ales, în lucrarea sa fundamentală. Spunem că renunțarea la pesimism a fost relativă, căci scepticul de la Frankfurt nu a început brusc să creadă că există un 'cer' deasupra noastră care ne veghează sau că oamenii-oricît de inteligențipot fi stăpînii propriei lor vieți, ci a trecut la un grad mult mai înalt de acceptare a limitelor vieții, idee de sorginte budistă și susținută de întreaga sa experiență de viață, pe care a dorit să o împărtășească semenilor prin intermediul paginilor sale. Este vorba, aici, despre adoptarea unei atitudini de oarecare împăcare și resemnare în fața neajunsului metafizic al vieții, cu tot ceea ce reprezintă ea sau cu ceea ce este reprezentat de ea, și de intenția de a oferi sfaturi în vederea obținerii unui confort mental și spiritual cît mai apropiat de noțiunea de 'fericire'. Etosul desprins din paginile Aforismelor poate fi rezumat—în mod forțat, desigur, dar extrem de plastic—prin îndemnul oximoronic: „Nu ai nici o șansă, dar folosește-o!” (Safranski, 1998, p. 353).

Aforismele lui A. Schopenhauer nu sînt scrise deloc într-un stil aforistic, filozoful german oferindu-ne aici un adevărat tratat de eudemonologie, noțiune explicată de autorul însuși, încă din primele rînduri:

Vreau să vorbesc despre arta de a duce o viață pe cît se poate de plăcută și de fericită, a cărei teorie s-ar putea numi eudemonologie: ea ar fi așadar călăuza existenței fericite. (Schopenhauer, 1969, 3).

Conform lui A. Schopenhauer, fericirea eudemonică, opusă celei hedonice, este cea obținută nu din plăceri și desfătări, ci din comportamentul circumspect și pesimist față de viață, evitînd astfel dezamăgirile ei inerente. Demonstrația la care recurge filozoful german ia forma unui mic tratat, cu șase capitole, în care discută aspectele existenței omenești. Deși aserțiunile apoftegmatice emise pe ton apodictic nu lipsesc ${ }^{3}$, larga respirație a textului, precum și stilul vioi și elaborat al frazelor indică vocația epică a unui filozof căruia plăcerea scrisului nu-i este străină.

Către sfîrșitul secolului al XIX-lea, Titu Maiorescu a decis să prezinte publicului românesc pe filozoful german Arthur Schopenhauer, traducîndu-i lucrarea cea mai de succes, Aforismele. Interesul constant al lui Titu Maiorescu pentru filozofie, care se manifestase încă de cînd acesta era elev la Viena, se grefează pe un interes continuu al intelectualilor din Țările Române pentru astfel de chestiuni. Preocupări pentru filozofie și, mai ales, pentru traduceri filozofice găsim încă din perioada Școlii Ardelene, ai cărei corifei au contribuit intens la emanciparea poporului prin cultură. În acest scop, pe lîngă scrieri științifice de istorie, lingvistică sau teologie, aceștia au tradus diverse scrieri filozofice occidentale, cele mai multe dintre acestea fiind, însă, simple manuale de filozofie sau lucrări de popularizare a științei, conținînd sfaturi practice pentru viaţa de zi cu zi a poporului. Un interes general al intelectualilor români din Transilvania, manifestat în același sens, se relevă și din faptul că, în 1795, se înființează o Societate filosofească a neamului rumânesc în mare principatul Ardealului, ai cărei inițiatori s-au pus în legătură cu intelectuali din Principatele Române, intuind astfel necesitatea unei colaborări pe plan intelectual și a unei unități posibile a întregii națiuni (Blaga, 1996, p. 207-210).

Despre traducerile din texte filozofice germane, realizate în perioada 1830-1860, adică in epoca imediat premergătoare Junimii, se poate spune că acestea sînt sensibil mai reduse ca număr decît cele beletristice, dar extrem de importante pentru formarea și fixarea terminologiei filozofice române moderne. O contribuție remarcabilă, în acest sens, o au traducerile în limba română ale unor manuale filozofice, publicate de către A. T. Laurian, S. Bărnuţiu, T. Cipariu sau Ghenadie Ienăceanu.

\footnotetext{
${ }^{3}$ Iată doar cîteva exemple extrase din Haack \& Haack (2013): Ein guter, gemäßigter, sanfter Charakter kann unter dürftigen Umständen zufrieden seyn; während ein begehrlicher, neidischer und böser es bei allem Reichthum nicht ist. (p. 16); Schönheit ist ein offener Empfehlungsbrief, der die Herzen zum Voraus für uns gewinnt. (p. 26); Denn je mehr Einer an sich selbst hat, desto weniger bedarf er von außen und desto weniger auch können die Uebrigen ihm seyn. (p. 28); Was Einer dem Andern seyn kann, hat seine sehr engen Gränzen: am Ende bleibt doch Jeder allein, und da kommt es darauf an, wer jetzt allein sei. (p. 30).
} 
Revenind la Titu Maiorescu, acesta îl citește pe Arthur Schopenhauer în timpul perioadei petrecute la Berlin (1858-1859), ca student al Facultății de filozofie, dar o face doar pentru a-l aprofunda pe Immanuel Kant, către care se îndreptau cele mai multe direcții ale filozofiei germane ale vremii. Printre lecturile sale, ca student la Berlin, se mai regăseau Spinoza, Voltaire și Feuerbach, iar doctoratul îl susține la Giessen, cu o lucrare despre filozofia lui Herbart.

Se pare că Arthur Schopenhauer i-a atras in mod deosebit atenția lui Titu Maiorescu, deoarece acesta s-a oprit asupra lui, pentru a traduce mai întîi Despre filozofia la Universitate, în 1870, și apoi un fragment din Parerga und Paralipomena, sub titlul Aforisme asupra înțelepciunii de viață, care va apărea în „Convorbiri literare", la nu mai mult de două decenii de la apariția lor în lumea culturală germană. Astfel, publicul românesc a avut ocazia de a-l cunoaște pe marele filozof german, care devenise interesant și prin influența pe care acesta o avea asupra creației lui Mihai Eminescu, promovată de Titu Maiorescu în aceeași perioadă, în revista Junimii.

Traducerea Aforismelor în limba română a fost publicată, aşadar, în revista „Convorbiri literare”, în perioada 1 aprilie 1876 - 1 martie 1877. Afirmația profesorului Liviu Rusu, conform căreia Aforismele tălmăcite de învățatul junimist ar fi fost publicate ,începînd cu anul 1872 pînă în 1877” (Rusu, 1969, p. XIV), nu este deloc falsă, însă trebuie nuanțată. Titu Maiorescu a început, într-adevăr, să publice traducerea Aforismelor la 1 noiembrie 1872, în nr. 8 al „Convorbirilor literare”, dar, dintr-un motiv necunoscut, nu a mai continuat-o în numerele următoare. T. Maiorescu reia publicarea abia în 1876, tot în paginile revistei Junimii, oferind o traducere completă, de această dată. Fragmentul publicat inițial, cel din 1872, constituit din Introducere și Cap. I: Impărțirea fundamentală, a fost reprodus aproape identic la reluarea publicării. Micile modificări de ortografie, care apar în textul publicat în perioada 1876-1877, reflectă instabilitatea sistemului ortografic al vremii. Pentru detalii în acest sens, a se vedea Bârlea (2013, p. 932). Astfel, în traducerea publicată în 1872, apar variante precum: „aci”, „espunerea”, „adecă” ș. a., care, în 1876, devin „aici”, „expunerea”, „adică” ș. a. Printre extrem de puținele modificări lexicale remarcăm înlocuirea adjectivului „presente” cu locuțiunea adjectivală „de față”.

În 1890, Titu Maiorescu decide să-şi publice traducerea într-un volum, la Editura Librăriei Socec din București. Următoarele ediții antume ale traducerii maioresciene, toate apărute la aceeași editură, au fost cele din 1891, 1902 și 1912 (Filimon-Stoicescu, 1969, p. XLIII). Din Prefața traducétorului la ediția din 1890, aflăm-de la Titu Maiorescu însuși-că a revăzut și a refăcut toată traducerea publicată inițial în „Convorbiri literare”, cu intenția afirmată de a acorda mai multă atenție particularităților stilului limbii române, stil pe care îl neglijase în detrimentul fidelității față de textul german (Maiorescu, 1890, p. VIIIIX). Se pare că adevăratul motiv al acestei revizii profunde este o observație făcută de Al. Odobescu cu privire la slaba calitate a traducerii publicate în revista Junimii (Vârgolici, 1997, p. 167). În anul următor, deci relativ imediat după prima publicare în volum, învățatul junimist scoate încă o ediție revizuită a traducerii, urmată de cea din 1902, care este considerată drept un „text definitivat, [...] reprodus fără stilizări și în 1912” (Filimon-Stoicescu, 1969, p. XLIV).

\section{Analiza contrastiv-diacronică a traducerii Aforismelor în limba română}

\subsection{Precizări asupra variantelor versiunii românești a Aforismelor}

Este de subliniat faptul că, avînd în vedere specificul temei, cele două modalități de analiză s-au întrepătruns în permanență, datorită dublului caracter al cercetării noastre: sincronic (prin confruntarea textului original cu traducerea sa) şi diacronic (prin confruntarea variantelor de traducere existente, care au fost efectuate de același traducător în perioade diferite).

În ceea ce privește variantele de traducere pe care le-am luat în considerare în cadrul analizei noastre, acestea sînt, după cum urmează: cele două variante publicate în „Convorbiri literare”, adică cea din 1872 și cea din 1876-1877, care sînt aproape identice și pe care le vom asimila una alteia, precum și două dintre variantele ulterioare, și anume, cea din 1890, prima publicată în volum, și cea din 1912, care este ultima ediție antumă a lui Titu Maiorescu și care este considerată definitivă. Așadar, discuția vizează cele trei 
variante ale versiunii românești, pe care le vom nota sintetic, utilizînd parțial anul publicării, după cum urmează:

\section{$\mathrm{A}_{72 / 76}$ : Aforisme pentru înțelepciunea în viață \\ $\mathrm{A}_{90}:$ Aforisme asupra înțelepciunii în viață \\ $\mathrm{A}_{12}$ : Aforisme asupra înțelepciunii în viață}

Diferențele rezultate din confruntarea variantelor menționate sînt în măsură să atragă atenția asupra ambiguităților semantice existente în textul-sursă, iar analiza acestora ne va ajuta să determinăm care au fost opțiunile de traducere ce au stat la îndemîna traducătorului român, într-o perioadă de intense prefaceri ale limbii române moderne, cum a fost cea de la sfîrșitul secolului al XIX-lea. De asemenea, vom încerca să determinăm care au fost motivațiile traducătorului în selectarea uneia dintre opțiuni și cum determină aceste selecții receptarea operei filozofice respective.

Lucrarea originală a lui Arthur Schopenhauer cuprinde o Introducere (Einleitung), urmată de șase capitole, după cum urmează: Capitolul I - Impărțirefundamentală (Kapitel I - Grundeinteilung), Capitolul II - Despre ceea ce este cineva (Kapitel II - Von dem, was einer ist), Capitolul III - Despre ceea ce are cineva (Kapitel III - Von dem, was einer hat), Capitolul IV - Despre ceea ce reprezintă cineva (Kapitel IV - Von dem, was einer vorstellt), Capitolul V - Parenese și maxime (Kapitel V-Paränesen und Maximen) și Capitolul VI - Despre deosebirea vîrstelor (Kapitel VI - Vom Unterschiede der Lebensalter). Cu mici excepții referitoare la ortografie, traducerea titlurilor acestor capitole a rămas nemodificată de-a lungul versiunilor publicate antum de Titu Maiorescu, ceea ce demonstrează că nu au existat ambiguități semantice care să necesite luarea în discuție a unor opțiuni de traducere existente. Acesta este motivul pentru care nu vom insista asupra acestui aspect, ci ne vom îndrepta atenția către traducerea titlului lucrării analizate.

\subsection{In jurul unui titlu}

În 1872, la prima apariție a traducerii Aforismelor în revista „Convorbiri literare”, Titu Maiorescu a tradus titlul original al lucrării lui Arthur Schopenhauer, Aphorismen zur Lebensweisheit, prin „Aforisme pentru înțelepciunea în viață”. La reluarea publicării, în 1876, Titu Maiorescu păstrează acelaşi titlu. Peste aproape douăzeci de ani, la publicarea în volum a Aforismelor, în 1890, acestea apar cu un titlu ușor modificat, și anume, „Aforisme asupra înțelepciunii în viață”, formulare care a rămas definitivă și în edițiile următoare, inclusiv în cea din 1912.

Comparînd cele două variante de traducere a titlului-pe de o parte varianta $\mathrm{A}_{72 / 76}$ și pe de altă parte variantele $\mathrm{A}_{90}$ și $\mathrm{A}_{12}$ - putem deduce cu ușurință că transpunerea în românește a titlului lucrării originale a ridicat, în mod evident, probleme de natură sintactică, semantică și pragmatică. Asupra acestora ne propunem să zăbovim pentru o primă discuție.

Traducerea românească, în ambele ei variante, respectă organizarea sintactică a titlului original, și anume, aceea de grup nominal, cu grup prepozițional inclus. Centrul grupului nominal este substantivul plural aforisme, care este un corespondent exact al germanului Aphorismen din titlul original. Cele două cuvinte provin, în ambele limbi, din latinescul aphorismus, care a fost adoptat din grecescul aphorismos. Limba germană a preluat acest neologism prin împrumut direct, din latină (cf. DUDEN, s.v. Aphorism) în timp ce în limba română există varianta adaptată fonetic, preluată tot din latină, prin intermediul limbii franceze (cf. DEX, s.v. aforism).

Titlul original include două substantive, dintre care unul este un compus (Lebensweisheit). În ambele variante ale traducerii românești intervin trei substantive, dintre care două (înțelepciunea / înțelepciunii și viață) explicitează compusul german. Corespondența de 2 la 3 , referitoare la numărul de substantive din titlul original și din traducerea în românește a acestuia, reflectă imposibilitatea de a găsi un corespondent perfect, în limba română, care să reflecte unul dintre principalele mijloace interne de îmbogățire a vocabularului limbii germane, acela de compunere prin juxtapunere. În cazul de față, compunerea s-a realizat prin alăturarea a două substantive, determinat și determinant (das Leben + die Weisheit), unite prin consoana de legătură $s$. Transpunerea totală în limba română a unui substantiv compus german într-un 
corespondent direct este imposibilă și se rezolvă, de obicei, prin descompunerea acestuia în constituenții săi și prin reasamblarea lor într-un grup nominal ${ }^{4}$ (Engel et al., 1993, p. 463).

În ambele variante de traducere, deci și în $A_{72 / 76}$ pe de o parte, şi în $A_{90}$ și $A_{12}$ pe de altă parte, Titu Maiorescu alege pentru compusul Lebensweisheit corespondentul românesc „înțelepciune în viață”. Așadar, optează pentru varianta cu grup prepozițional inclus și selectează prepoziția în ca centru al acestuia. În mod surprinzător, însă, chiar în prima frază a variantelor publicate în volum, în 1890, respectiv în 1912, T. Maiorescu decide ca, pentru același compus german, să recurgă la descompunerea cu genitiv inclus și își începe traducerea capitolului intitulat Introducere astfel:

Ințelepciunea vieții o iau aici in ințelesul obicinuit al cuvěntului fără vre o metafisică transcendentă. (Schopenhauer, 1890, 3).

În ambele cazuri, elementul subordonat, realizat fie printr-un genitiv, fie printr-un grup prepozițional, funcționează sintactic ca atribut al centrului grupului nominal, restrîngînd semantic clasa de obiecte pe care o desemnează acesta. Utilizarea genitivului, însă, introduce pentru substantivul vieţii rolul tematic de posesor.

Aparenta inconsecvență în traducerea acestui compus german este determinată de stilistica frazei românești. Probabil că T. Maiorescu a utilizat traducerea prin restricționare la cazul genitiv a elementului subordonat pentru a evita utilizarea repetată a prepoziției în, care reapare, în frază, la o distanță foarte mică de corespondentul românesc al substantivului compus german.

Această relativă instabilitate a formei elementului subordonat (genitiv sau grup prepozițional) este cauzată de faptul că, în limba română, nu există un principiu unic de traducere a substantivelor compuse germane și, cu atît mai puțin, nu există prepoziții prescrise pentru explicitarea lor. Singura condiție este ca ultimul substantiv din compusul german, așa-numitul determinant al compusului, să devină centrul grupului nominal românesc. Așadar, traducerea în limba română a unui substantiv german compus nu este egală cu suma traducerilor constituenților săi, ci presupune o construcție sintactică mai complexă decît simpla juxtapunere de substantive din cuvîntul din limba-sursă, oricît de complicată ar fi aceasta. Atunci cînd traducătorul alege să exprime elementul subordonat din cadrul grupului nominal printr-un grup prepozițional, acesta trebuie să-și activeze atît creativitatea, cît și competenţa sa lingvistică în raport cu limba-țintă, deoarece centrul grupului prepozițional, adică prepoziția însăşi, lipsește în corespondentul din limba-sursă. Prepoziția definește relația dintre cele două substantive, căpătînd astfel o importanță decisivă în receptarea corectă a intenționalității textului. În acest sens, determinantă în selectarea prepoziției celei mai potrivite este, credem noi, înțelegerea profundă a contextului în care apare, precum și a textului în ansamblu.

Un alt nod în care se concentrează mai multe sensuri este reprezentat de unitatea lexicală zur, care se află poziționată între cele două substantive din titlul original și care constituie, de fapt, o restrîngere, într-un singur lexem, a prepoziției $z u$ și a articolului $d^{2} r^{5}$. Spre a traduce acest lexem, Titu Maiorescu

${ }^{4}$ În limba română, descompunerea a unui substantiv german compus, construit prin alăturarea a două substantive, se realizează sub formă de grup nominal cu două substantive. De exemplu:

(1) germ. der Zimmerschlüssel - rom. cheia camerei,

(2) germ. das Hotelzimmer - rom. cameră de hotel.

Din cele două exemple de mai sus observăm că primul substantiv este centrul grupului, deși corespunde semantic determinantului, adică celui de-al doilea substantiv din compunerea germană, în timp ce al doilea substantiv este un element subordonat în cadrul grupului nominal și corespunde determinatului, adică primului substantiv din compunere. Posibilităţile de subordonare presupun restricționarea la cazul genitiv a substantivului din elementul subordonat, ca în exemplul (1) sau includerea acestuia într-un grup prepozițional, ca în exemplul (2). Uneori, cele două substantive apar într-o relație de coordonare (ca, de exemplu, copil-minune, pentru compusul german das Wunderkind), însă aceste cazuri nu sînt, deocamdată, foarte relevante pentru discuția noastră. Pentru mai multe detalii, vezi Engel et al. (1993, p. 463-471).

${ }^{5}$ Conform sintaxei limbii germane, conectorul zu impune complementului său, substantivul Lebensweisheit, forma cazuală de dativ, a cărui marcă este evidențiată proclitic prin articolul hotărît feminin în dativ (der). Prin contragerea articolului cu prepoziția respectivă se ajunge la forma derivată $z u r$. 
alege prepoziția pentru în $\mathrm{A}_{72 / 76}$, în timp ce în $\mathrm{A}_{90}$ și în $\mathrm{A}_{12}$ decide să reformuleze parțial titlul, așa cum am arătat mai sus, înlocuind prepoziția inițială cu prepoziția asupra. Acest lucru demonstrează, pe de o parte, polisemia prepoziției $z u$ din limba germană, dar și dificultăţile de transpunere a prepozițiilor, în general, dintr-o limbă în alta, pe de altă parte.

Înainte de a discuta implicațiile semantice ale celor două variante de titlu, determinate tocmai de prepozițiile utilizate, trebuie să observăm din nou că, în ambele variante, T. Maiorescu alege grupul nominal ,înțelepciune în viață” pentru traducerea compusului german Lebensweisheit. În momentul selectării prepoziției în, traducătorul a avut la îndemînă o serie de variante la care a renunțat, cum ar fi: ,înțelepciune de viață”, ,înțelepciune pentru viață” sau ,înțelepciune despre viață”. Considerăm că varianta aleasă de învățatul junimist este cea mai potrivită cu contextul lucrării lui A. Schopenhauer, deoarece autorul german se referă pe întreg parcursul textului său la obținerea fericirii și mulțumirii de-a lungul unei existențe omenești, cu alte cuvinte la obținerea înțelepciunii în viață.

Revenind la lexemul zur, trebuie să precizăm că, în limba germană, prepoziția $z u$ poate fi o prepoziție locală, temporală sau finală, dar contextul în care apare în discuția noastră exclude aspectul temporal, precum și pe cel local. Semantic vorbind, conectorul $z u$ se află în aceeași paradigmă cu prepoziția germană für (rom: pentru) și este utilizată atunci cînd finalitatea este exprimată prin substantive abstracte (Engel et al., 1993, p. 850-851), în cazul de față, prin femininul Lebensweisheit.

În $A_{72 / 76}$, conectorul pentru este o prepoziție lexicală, care impune acuzativul pentru substantivul articulat înțelepciunea și atribuie acestuia rolul de beneficiar. În această lumină, am putea deduce că aforismele ar avea o finalitate, și anume aceea de a obține-cu ajutorul lor-înțelepciunea în viață. În variantele $A_{90}$ și $\mathrm{A}_{12}$, T. Maiorescu procedează la o reformulare a titlului pe baza aceleiași scheme sintactice. Reformularea titlului se referă, de fapt, la înlocuirea prepoziției regente pentru cu lexemul de aceeași categorie morfologică asupra. Această modificare, aparent minoră, schimbă nu numai cazul elementului subordonat (care devine acum dativul ințtelepciunii), ci și intenționalitatea exprimării. Cititorul ar putea deduce acum că va citi niște aforisme despre înțelepciunea în viață, deci niște cugetări concise și memorabile, referitoare la subiectul respectiv. Or, măcar din punctul de vedere al formei, stilul scriiturii la care ne referim aici nu este nicidecum concis și sentențios, ci elaborat, cu fraze lungi, pe alocuri chiar dificil de descifrat. În plus, intenția autorului, care rezultă din textul în ansamblul său, nu este aceea de a prezenta o serie de panseuri filozofice în legătură cu o anumită temă, ci aceea de a-i conduce pe cititorii săi către un nivel superior de înțelegere a vieții.

Așadar, din punctul nostru de vedere, prima variantă de traducere pare mai potrivită cu intenționalitatea autorului textului-sursă, aceea de a oferi semenilor sfaturi pentru a-și duce existența cu înțelepciune, obținînd—astfel—fericirea și mulțumirea în viață, conform accepțiunii filozofului german. Această părere se sprijină pe faptul că Aforismele schopenhaueriene sînt mai degrabă un tratat filozofic explicativ, care îmbină—într-un stil relativ accesibil—-teoria (axiologia aspectelor importante din viaţa unui om) și practica (A. Schopenhauer își ilustrează considerațiile filozofice cu exemple aflate la îndemîna tuturor, într-un mod extrem de practic) și care are o finalitate explicită (obținerea plăcerii și fericirii în viață), afirmată deseori, pe parcursul textului, de însuşi autorul lui.

\subsection{O analiză pragmalingvistică a unităților aforistice}

În cele ce urmează, vom proceda la o analiză detaliată a traducerii capitolului intitulat „Introducere” (Einleitung) din Aforismele lui Arthur Schopenhauer. Textul original din limba germană a fost descompus în 14 elemente, corespunzătoare celor 14 enunțuri integrale ${ }^{6}$ din care este alcătuit. Analiza va cuprinde așezarea în paralel a fiecărui enunț din textul original cu cele trei variante de traducere în limba română pe care am hotărît să le analizăm și va urmări examinarea contrastivă a acestora, din mai multe puncte de vedere: lexico-semantic, morfologic, sintactic și stilistico-pragmatic.

\footnotetext{
${ }^{6}$ Utilizăm sintagma „enunț integral” cu sensul 'fragment de text cuprins între două puncte', sens care nu se suprapune perfect peste cel al cuvîntului 'frază' (cf. GBLR), pe care, totuşi, îl utilizăm deseori drept sinonim, în schimb, corespunde semantic conceptului Periode ( $\approx$ 'frază complexă), din gramatica germană (cf. Admoni, 1987, p. 23).
} 
Cecilia-Iuliana Vârlan

Obiectivul analizei noastre este relevarea manierei în care autorul originalului și-a organizat textulde la selecția lexico-semantică pînă la structurarea propozițiilor și frazelor, iar de aici, la valorificarea resurselor stilistice ale limbii-pentru a obține un anumit efect în plan cognitiv, dar și în plan estetic, pe de o parte, precum și măsura în care această intenționalitate pragmatică a fost bine înțeleasă și corect redată în limba sa de către traducătorul român.

Evident, am ținut seama în permanență de resursele celor două limbi, în epoca respectivă, de contextul istoric și cultural în care au apărut textul-sursă, respectiv, textul-țintă, precum și de penuria instrumentelor specifice de lucru care au stat la dispoziția traducătorului: la vremea cînd Titu Maiorescu realiza versiunea românească a Aforismelor nu exista încă un dicționar bilingv pe relația germană-română, ci doar unul, al filologului H. Tiktin, alcătuit pe relația inversă - română-germană (și care a început, de fapt, a se tipări abia în anul 1895), fără a uita să amintim aici existența deja celebrului Lexicon de la Buda, din 1825, al lui Petru Maior, cuprinzînd o serie de termeni românești pentru care erau oferite echivalente în limbile latină, maghiară şi germană.

Ca procedură practică de lucru, am decupat, așadar, textul original în fraze pe care le-am numerotat de la (1) la (14) și am consemnat versiunile românești succesive corespunzătore, conform notațiilor utilizate anterior: $A_{72 / 76}, A_{90} s, i A_{12}$.

După cum era de așteptat, prima frază a textului ne face o succintă introducere referitoare la noțiunea filozofică luată în discuție de autor în scrierea sa. Expunîndu-și propria viziune asupra termenului, autorul încearcă—de fapt—să construiască o definiție a acestuia.

(1) Ich nehme den Begriff der Lebensweisheit hier gänzlich im immanenten Sinne, nämlich in dem der Kunst, das Leben möglichst angenehm und glücklich durchzuführen, die Anleitung zu welcher auch Eudämonologie genannt werden könnte: sie wäre demnach die Anweisung zu einem glücklichen Daseyn.

A $_{72 / 76}$ Ințelepciunea in viață o iau aici numai in ințeles imanent, cuprinzěnd arta de a duce o viață pe căt se poate de plăcută și fericită, a cárei teorie s’ar putè numi și Eudamonologie; ea ar fi dar invěțătura existenței fericite.

$\mathrm{A}_{90} \quad$ Ințelepciunea vieții o iau aici in ințelesul obicinuit al cuvěntului fără vre o metafisică transcendentă. Vreau să vorbesc despre arta de a duce o viață pe cît se poate de plăcută și de fericită, a cărei teorie s’ar putè numì Eudemonologie: ea ar fi aşa dar călăuza existenței fericite.

$\mathrm{A}_{12}$ Înțelepciunea vieței o iau aici in înțelesul obișnuit al cuvîntului fără vreo metafizică transcendentă. Vreau să vorbesc despre arta de a duce o viață pe cît se poate de plăcută și de fericită, a cărei teorie s-ar putea numi eudemonologie: ea ar fi așadar călăuza existenței fericite.

O examinare rapidă a celor trei variante de traducere ale frazei (1) ne conduce către observația că $A_{90}$ și $\mathrm{A}_{12}$ sînt identice, cu excepția unor mici modificări datorate procesului de căutare a unui sistem unanim acceptat al ortografiei. Rapid detectabilă este, de asemenea, și instabilitatea ortografică a substantivului Eudemonologie. Inițial, în $\mathrm{A}_{72 / 76}$, Titu Maiorescu transferă direct acest cuvînt în limba română, fără ai modifica nici măcar ortografia (provenită din limba latină). Apoi, din dorința evidentă de a româniza acest neologism, măcar din punct de vedere formal, îl trece succesiv prin formele Eudemonologie (în $\mathrm{A}_{90}$ ) şi eudemonologie (în $\mathrm{A}_{12}$ ).

Prima variantă de traducere $\left(\mathrm{A}_{72 / 76}\right)$ urmărește exact, din punct de vedere sintactic, organizarea textului original. Acesta include o propoziție finită principală complexă (constituită în jurul predicatului nehme), o subordonată relativă (organizată în jurul formei verbale finite genannt werden könnte) și o propoziție principală (construită cu conjunctivul wäre). Aceasta din urmă este izolată de propoziția anterioară prin punctuație (prin semnul grafic 'două puncte'). Traducerea în limba română consemnează, ca echivalenți pentru predicatele de mai sus, următoarele forme: [o] iau, s'ar puté numi, repectiv ar fi. 
În variantele ulterioare $\left(A_{90}\right.$ și $\left.A_{12}\right)$, traducătorul reorganizează textul din punct de vedere sintactic, motivul fiind adjectivul german immanent, din sintagma im immanenten Sinne. În fapt, Titu Maiorescu renunţă la traducerea literală a germanului immanent și procedează la înlocuirea neologismului imanent cu o parafrază:

[înțelesul] obişnuit [al cuvîntului] fără vreo metafizică transcendentă.

Renunțarea la neologism determină, deci, o traducere prin parafrazare și, în consecință, o reorganizare sintactică a textului, prin fragmentarea propoziției inițiale, impusă de suplimentarea numărului de cuvinte din enunțul inițial și de evitarea unei sintaxe încărcate. Traducerea fragmentului următor-care, în textul original, începe cu adverbul nämlich — este reluată într-o frază nouă, care începe cu construcția „vreau sa vorbesc despre [...]”. Această sintagmă, și în special asocierea verbului a vorbi cu prepoziția despre, păstrează semantica adverbului german nämlich, care servește introducerii unei aserțiuni explicative și care poate $f i$ echivalat în românește prin adică sau „mai exact (spus)”. În prima variantă de traducere, Titu Maiorescu a ales drept corespondent-într-un mod destul de nefericit, credem noi-gerunziul cuprinzènd, respectînd astfel sintactica originală în detrimentul clarității mesajului din limba română. O variantă care ar conserva fidelitatea față de conținut, dar și pe cea față de formă, în aceeași măsură, ar putea fi cea în care s-ar utiliza chiar adverbul apozitiv adică, intenția fiind aceeași cu cea din textul original, și anume, explicarea anaforică a sintagmei ,în înțeles imanent“ (im immanenten Sinne):

[Înțelepciunea în viață o iau aici numai] în înțeles imanent, adică în acela al artei de a duce o viață [...].

Din punct de vedere lexical, tot prima variantă de traducere $\left(A_{72 / 76}\right)$ este cea care respectă, cu mici excepții, schema textului original. Excepția cea mai importantă-care se conservă, de altfel, și în variantele ulterioare-este reprezentată de faptul că Titu Maiorescu renunță la traducerea substantivului Begriff (rom.: noțiune, idee, termen, concept), care, în textul original, este un centru de grup nominal (den Begriff der Lebensweisheit $\rightarrow$ rom. conceptul de înțelepciune în viață). Astfel, traducătorul decide să introducă cititorului direct noțiunea de Lebensweisheit, căreia îi păstrează aceeași funcție sintactică de complement direct, pe care a avut-o întregul grup nominal din textul original. Renunțarea la traducerea centrului Begriff intensifică importanța elementului în discuție, adică a compusului german Lebensweisheit, care era, inițial, doar un element modificator (prin restricție) al centrului de grup și, deci, subordonat al acestuia. În traducerea românească, el devine nu doar independent, ci și tematizat, ceea ce îi acordă—pe bună dreptate!_importanța presupusă de însuși titlul lucrării.

O altă deosebire faţă de textul german, în ceea ce privește schema lexicală a traducerii românești, opțiune care se conservă, de asemenea, în toate cele trei variante analizate aici, este lipsa corespondentului pentru pronumele personal $i c h$, cu care A. Schopenhauer își deschide expunerea. Cauzele acestei omisiuni rezidă, pe de o parte, în decizia traducătorului de a tematiza complementul direct Lebensweisheit (devenit „înțelepciunea în viață”, respectiv, „înțelepciunea vieții”). Traducătorul realizează acest lucru prin modificarea topicii naturale a limbii române, care ar fi impus ca obiectul direct să fie așezat imediat după verb. Pe de altă parte, sintaxa limbii române permite ca pronumele personal eu, cu funcție de subiect, să rămînă neexprimat, fiind recuperat în totalitate din flexiunea verbală. Din punct de vedere pragmatico-semantic, utilizarea topicii naturale din limba germană îl ajută pe A. Schopenhauer să sugereze importanța pe care autorul însuși o acordă propriului mod de a gîndi și de a opera cu concepte filozofice. Așadar, în textulsursă, accentul este plasat pe individualitatea autorului, în timp ce, în textul-țintă (în toate variantele lui), atenția se focalizează pe sintagma care exprimă tema lucrării, și care este inclusă—de altfel一și în titlul acesteia. Dacă traducătorul ar fi păstrat în limba română topica germană și și-ar fi început enunțul cu pronumele $e u$, atunci ar fi rezultat o accentuare vădită a acestuia, accentuare care este doar sugerată de autorul textului-sursă, nicidecum evidențiată. Totuși, considerăm că varianta aleasă de Titu Maiorescu drept definitivă nu contravine prea mult intenționalității textului original și, în plus, respectă sintaxa și 
stilistica limbii române, nu numai din acel moment al stadiului de dezvoltare al ei, ci și din momentul actual.

Tot din punct de vedere lexical, este de remarcat efortul lui Titu Maiorescu de a găsi cel mai potrivit corespondent pentru substantivul german Anweisung, pentru care, în $\mathrm{A}_{72 / 76}$, utilizează un derivat al unui cuvînt moștenit din latină, și anume inveétătura. În variantele ulterioare, învăţatul junimist retraduce acelaşi cuvînt prin călăuza, un termen provenit din limba turcă. Decizia retraducerii ar putea proveni din faptul că derivatul învățătură i se va fi părut mai general sau mai vag decît călăuza, acesta din urmă sugerînd punctual ideea de 'conducere spre o idee', 'spre un țel'.

Ca orice traducător, Titu Maiorescu a avut de înfruntat problema definițiilor. Orice definiție este dificilă prin natura sa, dar cînd se definesc concepte abstracte, tipice limbajului filozofic, gradul de dificultate crește enorm. Or, aici ne aflăm la începutul textului, adică în pasajul în care autorul simte nevoia să-și clarifice conceptele cu care operează.

(2) Dieses nun wieder ließe sich allenfalls definiren als ein solches, welches, rein objektiv betrachtet, oder vielmehr (da es hier auf ein subjektives Urtheil ankommt) bei kalter und reiflicher Ueberlegung, dem Nichtseyn entschieden vorzuziehn wäre.

A privită in noi (căci aici judecata subjectivă trebue să hotărească) cu reflecție rece și matură, ar fi de sigur preferabilă neexistenței.

A $90 \quad$ Aceasta insě s’ar putè earăși definì ca o existenţă, care privită in sine insăş sau mai bine privită in noi (căci aici judecata noastră personală trebue să hotărască) cu mintea rece și matură, ar fi de sigur preferabilă neexistenței.

$\mathrm{A}_{12} \quad$ Aceasta însă s-ar putea iarăși defini ca o existență, care privită in sine insași, sau mai bine privită in noi (căci aici judecata noastră personală trebue să hotărască) cu mintea rece și matură, ar fi de sigur preferabilă neexistenței.

Variantele $A_{90}$ și $A_{12}$ sînt, de asemenea, relativ identice (cu micile modificări ortografice inerente), iar organizarea sintactică este aceeași cu cea din original, în toate cele trei variante de traducere analizate.

În fraza anterioară (1), pasivul german genannt werden könnte a fost tradus de T. Maiorescu prin „s-ar putea numi". Așadar, a fost utilizată forma de pasiv, construită cu pronumele reflexiv se, ceea ce constituie o alegere foarte potrivită, întrucît această formă de pasiv este preferabilă în textele tehnice și în cele științifice (Engel et al., 1993, p. 397).

În fraza de faţă (2), aceeaşi construcție cu reflexivul se este utilizată pentru o altă formă de pasivizare din limba germană, și anume, cea care folosește verbul lassen cu sens impersonal și reflexiv ${ }^{7}$.

În textul original, verbul lassen a fost utilizat la modul conjunctiv (ließe), formă a cărei încărcătura semantică a fost preluată, în românește, de modalul a putea. În fapt, originalul nu exprimă ideea de 'potențialitate', ci pe aceea de 'posibilitate': cum este posibil / am putea defini un concept aflat în discuție. Așadar, opțiunea lui T. Maiorescu de a introduce un verb modal suplimentar în versiunea românească, pentru a acoperi un sens al verbului original, care ar fi rămas—altfel—neacoperit, pare perfect îndreptătitiă.

În ceea ce privește perechea de termeni objektiv / subjektiv din textul original, este evident că traducătorul a întîmpinat o serie de dificultăţi în luarea unei decizii referitoare la transpunerea celor două cuvinte germane în românește. Pentru adverbul objektiv, care apare în sintagma „(rein) objektiv (betrachtet)”, traducătorul evită transpunerea directă a termenului în discuție și procedează la o adaptare a acestuia. Astfel, în toate cele trei variante de traducere, amintita sintagmă devine: „(privită) în sine însăşi”. Cel de-al doilea membru al relației, adjectivul subjektiv, este tradus literal doar în prima variantă de traducere (în $\mathrm{A}_{72 / 76}$ ), unde apare sub forma subjectivă, însă nici aici Titu Maiorescu nu este totalmente satisfăcut

\footnotetext{
${ }^{7}$ Trecerea la diateza pasivă cu ajutorul impersonalului reflexiv al verbului german lassen are drept corespondent în limba română, în mod prescriptiv, o construcție activă cu reflexivul se (Engel et al., 1993, p. 411), construcție aleasă și de Titu Maiorescu pentru traducerea sa.
} 
de această echivalare, astfel încît recurge la o adăugare explicativă, deci la o supra-traducere. În acest sens, traducătorul introduce-puțin mai devreme în frază_sintagma „privită în noi”, care nu există în textul original, preluînd forma de exprimare utilizată pentru echivalarea adverbului objektiv și punînd, astfel, cei doi termeni într-o relaţie de corespondenţă. Sintetizînd, în varianta de traducere $A_{72 / 76}$, cei doi termeni germani discutați apar echivalați în românește în felul următor:

- objektiv $\rightarrow$ (privită) în sine însăşi

- subjektiv $\rightarrow$ (privită) în noi + (judecata) subiectivă

În variantele ulterioare $\left(\mathrm{A}_{90}\right.$ și $\left.\mathrm{A}_{12}\right)$, neologismul subjectivă este înlăturat total din text, fiind înlocuit de două adjective (noastră și personală), sintagma corespunzătoare devenind „(judecata) noastră personală”.

Această manieră de a traduce prin evitarea transpunerii literale a unui cuvînt este aplicată de Titu Maiorescu în special în situațiile în care se impune inserarea în text a neologismelor provenite din limba latină, învățatul junimist considerînd, așa cum am mai arătat anterior, că acestea nu sînt absolut necesare, atît timp cît există variante autohtone de echivalare. După părerea noastră, însă, evitarea utilizării acestor neologisme îngreunează receptarea mesajului conținut în textul original de către cititorul actual, cu toate că intenția traducătorului a fost, în mod evident, să găsească un mod de comunicare apropiat de vorbitorii de rînd ai limbii române de la momentul realizării traducerii (sfîrșitul secolului al XIX-lea și începutul secolului al XX-lea).

În același sens, al preîntîmpinării apariției unor neclarități în procesul de receptare, T. Maiorescu decide să renunțe la echivalarea în românește a unui pronume demonstrativ, alegînd să insereze, în textul său, substantivul la care se referă demonstrativul respectiv. Astfel, substantivul Daseyn, menționat în fraza (1) a textului original, este substituit în fraza (2) de locuțiunea demonstrativă ein solches, care se află în corespondență și cu demonstrativul dieses din acelaşi enunţ. Corelaţia acestor două pronume demonstrative cu substantivul menționat este foarte clară în textul-sursă, deoarece ambele poartă marca neutrului, prin terminația - $(e) s$, iar singurul substantiv neutru anterior, la care aceste demonstrative ar fi putut face referire, este cel pe care l-am menționat. În limba română, corespondentul lui Daseyn este substantivul feminin 'existenţă'. Dacă traducătorul ar fi urmat neabătut schema textului original (2), ar fi rezultat o exprimare de tipul:

\section{Aceasta s-ar putea iarăși defini ca una, care $[\ldots]$}

În acest moment, cititorul va încerca să descifreze mecanismul anaforic, căutînd corelatul pronumelui una în enunțul anterior, unde va găsi nu mai puțin de șase substantive feminine (existenței, călăuza, eudemonologie, teorie, viață și artă). Introducerea în discurs a substantivului nu este deloc o alegere nefericită a traducătorului, ci, dimpotrivă, concretizează referința și dezambiguizează mesajul, fără să-l îngreuneze prin repetiții deranjante.

O altă dificultate de traducere o constituie transpunerea substantivului postverbal Ueberlegung, pentru care orice dicționar bilingv returnează echivalente ca reflecție, reflectare, cugetare sau chibzuială (cf. D GR, s.v. Überlegung). Primul termen din această serie este și cel utilizat de T. Maiorescu, în varianta inițială $\left(A_{72 / 76}\right)$. În variantele ulterioare, însă, corespondentul utilizat de învățatul junimist este substantivul minte, care nu se regăsește în seria sus-menționată. Este evident că decizia de retraducere provine dintr-o nemulțumire a traducătorului și, în acest caz, ca în multe altele, ni se pare binevenită. Nemulțumirea traducătorului T. Maiorescu a fost provocată, pe de o parte, de suprapunerea semantică dintre verbul „a privi ceva”, aici cu sensul 'a reflecta la ceva', și substantivul reflecţie. Pe de altă parte, contextul unei expresii ca „(a privi ceva) cu mintea rece și matură”, pe care traducătorul o introduce în $\mathrm{A}_{90}$, implică tocmai modalitatea de a considera ceva (sau, altfel spus, de a reflecta la ceva) cu obiectivitate şi bazîndu-te pe o anumită experiență de viață, ceea ce reprezintă cu exactitate sensul ideii expuse în textul original.

Urmează o înlănțuire de enunțuri cu caracter explicativ, obișnuite în operația de clarificare suplimentară a conceptelor operaționale. Fraza care urmează ne oferă prilejul de a vedea cum se face transferul de la abstract la concret, în discursul filozofic. 
(3) Aus diesem Begriffe desselben folgt, daß wir daran hiengen seiner selbst wegen, nicht aber bloß aus Furcht vor dem Tode; und hieraus wieder, daß wir es von endloser Dauer sehn möchten.

$A_{72 / 76}$ Din acest ințeles al ei urmează, că am iubì-o pentru ea insași, nu numai de frica morții; și din aceasta earăși, că am dorì să o vedem de o durată nesfirșită.

$\mathrm{A}_{90} \quad$ Din acest ințeles al ei urmează, că am iubì-o pentru ea insăș, nu numai de frica morțiii și din aceasta iarăș, că am dorì să o vedem nesfirșit de lungă.

$\mathrm{A}_{12}$ Din acest ințeles al ei urmează, că am iubì-o pentru ea însăși, nu numai de frica morțiii și din aceasta iarăși, că am dorì să o vedem nesfirșit de lungă.

Traducerea, în toate cele trei versiuni ale ei, urmează schema lexicală și sintactică a textului original, cu toate că expresia cu care începe fraza (3), și anume, Aus diesem Begriff desselben, pune la încercare, încă o dată, abilitățile de traducător ale lui Titu Maiorescu. Ne reamintim că, în transpunerea românească a enunțului (1), termenul Begriff fusese eludat complet. De această dată, el nu mai poate fi evitat și este echivalat prin substantivul ințteles. Această corespondență între cele două cuvinte nu se regăsește ca atare printre opțiunile oferite de dicționarele bilingve actuale, dar acoperă, după părerea noastră, acea zonă semantică a înțelegerii conceptelor, implicată de expresii de tipul:

germ. schwer/langsam vom Begriff sein - rom. a fi incet/repede la minte, a pricepe cu greutate/cu uşurință.

De altfel, verbul begreifen, din care provine acest substantiv, are drept sinonim pe verstehen, care înseamnă, fără echivoc, 'a înțelege', ceea ce validează, o dată în plus, decizia traducătorului.

Precum am mai precizat aici, Titu Maiorescu a recurs, pe o scară destul de largă, la traducerea literală, lucru vizibil cu precădere în varianta $A_{72 / 76}$. Acesta este și cazul a două expresii din enunțul de față: und bieraus wieder („din aceasta iarăși”) și von endloser Dauer („de o durată nesfirșită”). Începînd cu varianta $\mathrm{A}_{90}$, unele dintre transpunerile literale au beneficiat de o retraducere prin rafinare stilistică, în raport cu limba română. Astfel, cea de-a doua expresie din exemplul de mai sus a devenit „nesfîrșit de lungă”, careprin utilizarea unui adverb adjectival (lungă) împreună cu a unui modificator adverbial pentru exprimarea gradului superlativ (nesfîş̧it de) — păstrează sensul originalului și constituie, totodată, o realizare mai fericită a circumstanțialului pentru predicatul să o vedem. Oricum, observăm că rezultatul final nu este o concretizare a explicației, ci doar o parafrazare definitorie mai accesibilă.

În construcția wir hiengen daran, Arthur Schopenhauer folosește conjunctivul verbului anhängen, în timp ce Titu Maiorescu alege să utilizeze varianta am iubi-o. Modul condițional-optativ al verbului din versiunea românească constituie o alegere îndreptățită a traducătorului, dacă ținem cont de posibilitățile limitate de traducere în românește a modului Konjunktiv german. Ceea ce ne reține atenția, însă, este alegerea verbului românesc a iubi drept corespondent al germanului anhängen. Dicționarele bilingve consemnează pentru acesta din urmă sensuri precum: 'a atîrna', 'a suspenda, 'a agăța, 'a ataşa', dar și o utilizare metaforică, de tipul Ich hänge an dir (rom.: te iubesc, țin la tine, sînt dependent de tine etc.) (cf. DGR, s.v. anhängen). Titu Maiorescu a remarcat imediat valoarea metaforică pe care autorul originalului a atribuit-o verbului utilizat în această construcție, selectînd pentru acesta sensul metaforic 'a atașa', care implică sentimentul față de un obiect concret sau abstract.

În unele secvențe explicative, Arthur Schopenhauer își pune sub semnul întrebării unele aspecte ale sistemului său filozofic, dar numai în plan retoric, căci revine repede cu decizia luată. Traducerea trebuie să rezolve acest conflict între îndoială (aparentă) și decizie (reală).

(4) Ob nun das menschliche Leben dem Begriff eines solchen Daseyns entspreche, oder auch nur entsprechen könne, ist eine Frage, welche bekanntlich meine Philosophie verneint; während die Eudämonologie die Bejahung derselben voraussetzt.

$\mathrm{A}_{72 / 76}$ De corespunde viața omenească unei asemene existenți sau de ar putè vre-odată să-i corespundă, este o intrebare, la care filosofia mea, după cum se știe, respunde negativ; pe cănd Eudæmonologia presupune un respuns afirmativ. 
$A_{90} \quad$ De se potrivește viața omenească cu o asemenea existență sau de ar putè vre-o dată să se potrivească, este o intrebare, la care filosofia mea, după cum se știe, respunde negativ; pe cînd Eudemonologia presupune un respuns afirmativ.

$\mathrm{A}_{12} \quad$ De se potriveste viața omenească cu o asemenea existență sau de ar putea să se potriveasca vreodată, este o întrebare, la care filozofia mea, precum se știe, răspunde negativ; pe cînd eudemonologia presupune un răspuns afirmativ.

Pentru verbul entsprechen, Titu Maiorescu alege, în varianta $\mathrm{A}_{72 / 76}$, echivalentul a corespunde, provenit din franceză (correspondre), unde fusese împrumutat din latina medievală (cf. LAROUssE, s.v. correspondre). Această opțiune de traducere poate fi considerată rapidă și naturală, deoarece ambele verbe au aceeași valență sintactică, restricționînd la cazul dativ substantivele sau pronumele cu care se pot combina. În variantele ulterioare, traducătorul reconsideră echivalentul românesc al lui entsprechen și îl înlocuiește cu reflexivul a se potrivi, un verb de origine slavă, pe care îl consideră—probabil-mai împămîntenit în limbajul cititorilor de la sfirșitul secolului al XIX-lea. În ambele cazuri, însă, corespondentul românesc nu are cum să acopere marca pe care o poartă verbul german, și anume, aceea a cazului denumit, în limba germană, Konjunktiv I (care nu are echivalent în limba română și care nu trebuie confundat cu conjunctivul românesc). Atunci cînd nu marchează vorbirea indirectă, utilizarea acestui caz semnaleazăca în cazul de faţă-irealitatea unei stări de fapt. Într-adevăr, atitudinea filozofului german este una de neîncredere față de adevărul acelei stări de fapt, căci, după cum însuși precizează, A. Schopenhauer-sau, mai degrabă, filozofia lui-neagă ipoteza expusă în construcția cu ob... + Konjunktiv I. Rezolvarea pe care o propune Titu Maiorescu este introducerea adverbului vreodată, a cărui încărcătură semantică, aceea de timp indefinit, reușește să transfere versiunii românești o parte din îndoiala care fusese realizată semantic, în original, prin modul verbal:

$\mathrm{A}_{72 / 76}$ : De corespunde viața omenească unei asemene existenți sau de ar putè vre-odată să-i corespundă ...

$A_{90}: \quad$ De se potrivește viața omenească cu o asemenea existență sau de ar putè vre-o dată să se potrivească ...

$\mathrm{A}_{12}$ : De se potriveste viața omenească cu o asemenea existență sau de ar putea să se potriveasca vreodată.

Din aşezarea în paralel a celor trei variante ale versiunii românești, observăm că adverbul vreodată a fost, iniţial, plasat între modalul ar putea și conjunctivul să corespundă, respectiv să se potrivească (vezi $\mathrm{A}_{72 / 76}$, respectiv $\mathrm{A}_{90}$ ). Aceasta este topica normală pentru limba germană, unde se impune ca verbul a cărui acțiune este modalizată să ocupe ultimul loc în propoziție. În $\mathrm{A}_{12}$, adverbul este deplasat spre imediata vecinătate a modalului ar putea, în conformitate cu norma topicii limbii române.

Traducătorul rămîne consecvent intenției sale de a ușura înțelegerea textului de către cititorii români și evită, și de această dată, traducerea termenului Begriff din sintagma dem Begriff eines solchen Daseyns, pe care o echivalează, în $A_{90}$, cu un complement indirect exprimat printr-un grup nominal în dativ („unei asemenea existenți”), respectiv, cu un complement prepozițional care include un grup nominal în acuzativ („cu o asemenea existență”), în $A_{12}$. Așadar, renunțînd la centrul grupului nominal din sintagma originală, traducătorul asimilează—de fapt—conceptul de existență existenței însăși, ceea ce constituie o oarecare îndepărtare faţă de textul-sursă. Dacă, însă, s-ar fi procedat la o traducere literală, textul românesc ar fi conținut mai mult de două substantive (grupuri nominale) implicate în relația biunivocă de corespondență reclamată de verb, ceea ce ar fi îngreunat perceperea mesajului.

Adverbul german bekanntlich, plasat de Arthur Schopenhauer în imediata vecinătate a grupului nominal meine Philosophie, induce ideea că cititorii Aforismelor ar fi fost deja familiarizaţi cu opera filozofului german, ceea ce nu corespunde-în fapt—realității. După cum am arătat în introducerea prezentei lucrări, istoricii literari și biografii lui Arthur Schopenhauer consemnează faptul că publicul vremii și-a îndreptat 
atenția către opera sa filozofică abia după ce Aforismele au repurtat un succes de public. Avem, aici, de-a face cu încă o dovadă a încrederii lui Arthur Schopenhauer în propriul său sistem filozofic și, mai mult, cu o oarecare undă de infatuare a unui autor care presupune că cititorii săi îi cunosc, în esență, opera anterioară. În românește, acest adverb a fost echivalat cu o locuțiune verbală, în toate cele trei variante ale versiunii traduse. În $A_{72 / 76}$, T. Maiorescu alege expresia „după cum se știe“, cu rol de conector pragmatic metadiscursiv. Revizuirea traducerii, prilejuită de publicarea în volum a Aforismelor, în 1890, nu produce nici o modificare a acestei expresii, pentru ca varianta finală, $A_{12}$, să înregistreze o altă formă, și anume, „precum se știe“. Aceasta este una dintre puținele ocazii în care putem observa diferențe, deși minore, între variantele $A_{90}$ și $A_{12}$.

Această frază (4) este prima dintr-o serie de precizări care va continua pînă la sfîrșitul acestui mic capitol introductiv, precizări prin care Arthur Schopenhauer operează o distincție clară între eudemonologie, pe de o parte, care constituie-de fapt-tema scrierii sale, și sistemul filozofic elaborat de autor anterior acestei scrieri, pe de altă parte. Autorul stabilește aici limitele abordării filozofice pe care o va întreprinde în lucrarea sa, delimitînd-o strict de opera sa anterioară, mai mult, punînd-o într-o oarecare opoziție cu aceasta. Acest conflict între cele două abordări este reflectat de opoziția dintre două grupuri verbale antonimice: (die Frage) verneinen și die Bejahungvoraussetzen. Pentru traducerea verbului german tranzitiv verneinen, Titu Maiorescu evită echivalarea directă cu un neologism provenit din latină (a nega) și recurge la locuțiunea verbală a răspunde negativ. Decizia aceasta provine, probabil, din faptul că utilizarea corespondentului direct al lui verneinen în acest context ('a nega o întrebare') modifică înțelesul din original și poate conduce către ideea (falsă) de contestare a utilității sau a legitimității întrebării respective.

Antonimul direct al verbului verneinen ar fi tranzitivul bejahen, însă autorul originalului recurge și el la o parafrază verbală, care include substantivarea tranzitivului respectiv: die Bejahung voraussetzen. În românește, verbul voraussetzen din parafraza verbală va fi tradus literal, prin corespondentul a presupune, în timp ce obiectul direct, grupul nominal die Bejahung derselben, va fi concretizat tot printr-un grup nominal („un răspuns afirmativ”), care acoperă, ca sens, doar substantivul die Bejahung. Observăm, deci, că T. Maiorescu omite traducerea pronumelui derselben, care are drept referent substantivul die Frage, iar acest lucru nu îl face din neatenție, ci cu intenția vădită de a nu îngreuna inutil sintaxa frazei românești, prin introducerea unui mesaj redundant: „un răspuns afirmativ ( ${ }^{*}$ la aceasta)”.

După ce pune în opoziție, în plan retoric, eudemonologia față de propriul său sistem filozofic, precum aminteam mai sus, Arthur Schopenhauer nu uită ca în fraza imediat următoare să motiveze-deși relativ lapidar-acest demers:

(5) Diese nämlich beruht auf dem angeborenen Irrthum, dessen Rüge das 49. Kapitel im 2. Bande meines Hauptwerks eröffnet.

A $_{72 / 76}$ Căci aceasta se intemeiază tocmai pe eroarea innăscută, cu a cărei critică incepe capitolul 49 in volumul al 2-le al opului meu principal $\left.{ }^{*}\right)$

$\left.{ }^{*}\right)$ Opul principal, in care se cuprinde filosofia lui Schopenhauer e die Welt als Wile und Vorstellung (lumea ca voința și idee). T.]

$\mathrm{A}_{90}$ Căci aceasta se intemeiază tocmai pe eroarea innăscută, cu a cărei critică incepe capitolul 49 din volumul al 2-lea al opului meu principal ${ }^{*}$

$\left[{ }^{*}\right)$ Opul principal, care cuprinde doctrina lui Schopenhauer e die Welt als Wile und Vorstellung (lumea ca voința și ca representare). Traducere franceză de d. I.A. Cantacuzin (Le monde comme volonté et comme représentation. 2 vol. Bucarest, Socec, 1886). Trad.]

$\mathrm{A}_{12}$ Căci aceasta se întemeiază tocmai pe eroarea înnăscută, cu a cărei critică incepe capitolul 49 din volumul al 2-lea al operei mele principale ${ }^{*}$

${ }^{*}$ ) Opera principala care cuprinde doctrina lui Schopenhauer, e die Welt als Wile und Vorstellung (Lumea ca voință și reprezentare). Traducere franceză de d. I.A. Cantacuzin (Le monde comme volonté et comme représentation. 2 vol. Bucarest, Socec, 1886). (Nota trad.)] 
Arthur Schopenhauer ne indică faptul că această frază reprezintă, din punct de vedere pragmatic, o explicație sau o justificare a demersului de care aminteam mai sus, prin utilizarea adverbului nämlich. Acesta, în poziție postpusă, poate fi echivalat cu conjuncția denn ('căci', 'pentru că', cf. DUDEN, s.v. denn). După cum era de așteptat, Titu Maiorescu îşi incepe fraza cu conjuncția „căci”, pe care o așează, conform normelor limbii române, la începutul propoziției explicative, pentru a exprima „motivul unei afirmaţiuni” (Șăineanu, 1908, p. 88).

Textul fragmentul original începe cu pronumele demonstrativ diese, al cărui referent trebuie să fie un substantiv feminin, singular. Pluralul iese din discuţie datorită mărcii enclitice de singular a verbului predicativ. Operațiunea de stabilizare a sensului acestui pronume nu este deloc facilă, deoarece contextul lingvistic precedent implică mai multe substantive feminine, pe care le enumerăm aici, în ordinea inversă a incidenței în fraza precedentă, deci în ordinea logică a căutării: (die) Bejahung, (die) Eudämonologie, (meine) Philosophie, (eine) Frage. Luînd în considerare logica pragmatico-textuală, pe de o parte, rezultă că probabilitatea cea mai mare ar fi aceea, ca referința să fi fost făcută la cel mai apropiat dintre substantivele existente în fraza precedentă, adică la primul din enumerarea noastră: (die) Bejahung. Nu trebuie să uităm, însă, că acestuia îi corespunde, în traducerea românească, masculinul „un răspuns”, al cărui corespondent pronominal ar fi acesta, și nicidecum aceasta, cum a tradus T. Maiorescu. Pe de altă parte, dacă ținem cont de faptul că acest substantiv este inclus, ca obiect direct, într-un grup verbal, și anume, die Bejahung derselben voraussetzt, atunci rezultă că referentul demonstrativului diese trebuie să fie următorul substantiv feminin, și anume, (die) Eudämonologie, ceea ce corespunde și logicii textuale (în românește, echivalentul acestui substantiv feminin este preluat prin împrumut direct, 'eudemonologie', deci corespondentul pronominal este aceasta), și celei situaționale (avem de-a face cu un fragment alcătuit din mai multe fraze care au ca temă eudemonologia, deci este firesc ca referenții aflați în cazul nominativ să corespundă acestui substantiv).

În fraza aflată în discuție există un cuvint-cheie, Irrthum ('greșeală', 'eroare'), pe care Titu Maiorescu îl traduce ca atare (eroare), în toate variantele versiunii românești. Acest cuvint se înscrie în critica pe care A. Schopenhauer o operează asupra teoriei eudemonologiei și semnalează, din punctul de vedere al filozofului german, caducitatea fundamentului pe care se bazează conceptele filozofice care aparțin acestei teorii și cu care va opera în scrierea sa. Grupul nominal, al cărui centru este acest substantiv, include adjectivul angeboren, pe care T. Maiorescu îl echivalează, în toate cele trei variante de traducere discutate aici, prin adjectivul înnăscută. La vremea respectivă, înnăscut însemna 'adus odată cu nașterea' (Șăineanu, 1908, p. 329). Acum, un sinonim notat de toate dicționarele contemporane este congenital, ceea ce nu mai corespunde mesajului inițial. Pentru cititorul actual, un echivalent mai potrivit pentru receptarea corectă a mesajului din textul-sursă ar fi adjectivul inerent.

Cele trei variante ale versiunii românești ale frazei discutate aici sînt identice, cu excepția unui substantiv, și anume opul, care devine opera abia în traducerea definitivă, cea din 1912, în conformitate cu evoluția limbajului filozofic românesc. Acest substantiv este preluat și în nota de subsol, a traducătorului, care este o notă explicativă, referitoare la lucrarea principală a lui A. Schopenhauer, la care autorul face referire în text, sub forma mein Hauptwerk, deci nenumind-o ca atare. Știind că elaborează o primă traducere în limba română din opera marelui filozof german, Titu Maiorescu simte nevoia să menționeze, pentru cititorii români, titlul acestei lucrări și, de asemenea, să ofere, începînd cu varianta $\mathrm{A}_{90}$, coordonatele complete ale traducerii acesteia în limba franceză ${ }^{8}$, singura accesibilă publicului românesc, exceptînd originalul.

Analizînd nota de subsol observăm diferențe de traducere datorate strict evoluției limbii române din acea vreme. Astfel, începînd deja cu varianta din 1890, apare formularea „care cuprinde” în loc de „in care se cuprinde" din $\mathrm{A}_{72 / 76}$, transformarea reflexivului în tranzitiv uşurînd, în mod evident, sintaxa frazei. Evoluția metalimbajului filozofic este, de asemenea, sesizabilă în faptul că T. Maiorescu, referinduse la sistemul filozofic al lui A. Schopenhauer cuprins în lucrarea amintită, notează inițial „filosofia lui Schopenhauer", pentru ca, în variantele ulterioare să revină cu substantivul doctrina. Demersul său este

\footnotetext{
${ }^{8}$ După cum se știe, Titu Maiorescu a contribuit la traducerea acestei opere importante, susținându-l一moralicește, mai cu seamă—pe traducător. A se vedea, în acest sens Maiorescu (1939, p. 345-346) și Rădulescu-Pogoneanu (1939, p. IX).
} 
o încercare de a restrînge sensurile cuvîntului filozofie la doar unul: 'sistemă particulară a unui filozof', renunțînd la sensurile mai generale, de 'știință [...] care interpretează și reflectă realitatea' sau 'concepție generală despre lume și viaţă’ (Șăineanu, 1908, p. 251). Titlul lucrării principale a lui A. Schopenhauer este tradus inițial prin „lumea ca voință și idee”. În $A_{90}$ apare formula „lumea ca voință și ca representare”, în timp ce, în varianta finală $\mathrm{A}_{12}$, apare formula care a rămas definitivă pînă astăzi, și anume, „Lumea ca voință și reprezentare”. În plus, apar diferențe în ceea ce privește înregistrarea addendum-ului explicativ ca notă a traducătorului. În $A_{72 / 76}$ apare notația „T., în $A_{90}$, T. Maiorescu notează „Trad.”, pentru ca, abia în $\mathrm{A}_{12}$ să apară formula utilizată și astăzi, „(Nota trad.)”.

În cea de-a doua parte a lucrării de faţă, vom continua analiza pragmalingvistică a fragmentului de text supus cercetării și vom prezenta, de asemenea, concluziile acestei cercetări.

\section{Bibliografie}

Admoni, W.G. (1987). Die Entwicklung des Satzbaus der deutschen Literatursprache im 19. und 20. Jahrbundert, Berlin.

Bârlea, P.Gh. (2013). Titu Maiorescu și sistemul ortografic al limbii române, în: Cap-Bun, M. \& Nicolae F. (eds.). Junimea și impactul ei după 150 de ani, Editura Universitară, București, p. 9-32.

Blaga, Lucian. (1996). Gândirea românească în Transilvania în sec. al XVIII-lea, Editura Științifică, București.

DEX = Dicționarul explicativ al limbii române, Academia Română, Editura Univers Enciclopedic Gold, București, 2012.

DGR = Dicționar german-român, Institutul de lingvistică „Iorgu Iordan - Al. Rosetti” al Academiei Române, Editura Univers Enciclopedic Gold, București, 2010.

DUDEN = Deutsches Universalwörterbuch, 3., neu berbeitete und erweiterte Auflage, Dudenverlag, Mannheim, Leipzig, Wien, Zürich, 1996.

Engel, U., Isbășescu, M., Stănescu, S. \& Nicolae, O. (1993). Kontrastive Grammatik Deutsch-Rumänisch, Julius Groos Verlag, Heidelberg.

Filimon-Stoicescu, D. (1969). Notă asupra ediției, în: Schopenhauer, 1969, p. XLIII-XLVI.

Frauenstädt, J. (Hrsg.) (1891). Arthur Schopenhauer's Sämmtliche Werke, 2. aufl. Neue Ausg., Fünfter Band. F. A. Brockhaus, Leipzig, p. 331-530.

GBLR = Pană Dindelegan, G. (coord.) (2010). Gramatica de bază a limbii române, Editura Univers Enciclopedic Gold, București.

Haack, H.-P. \& Haack, C. (eds.) (2013). Schopenhauer: Aphorismen zur Lebensweisheit, Antiquariat und Verlag Dr. Haack, Leipzig.

LAROUSSE = Dictionnaire de français (Larousse), [online].

Maiorescu, T. (1890). Prefaţa traducétorului, în Schopenhauer, 1890, p. VIII-IX.

Maiorescu, T. (1939). Insemnări zilnice, publicate cu o introducere, note, facsimile şi portrete de I. Rădulescu-Pogoneanu, vol. II (1881-1886), Editura Librăriei Socec \& Co. S.A., București.

Maiorescu, T. (1980). Prelegeri de filozofie, ediție îngrijită, note și comentarii de Grigore Traian Pop și Alexandru Surdu, cuvînt înainte de G. T. Pop, Editura Scrisul Românesc, Craiova.

Rădulescu-Pogoneanu, I. (1939). Introducere la Maiorescu, 1939.

Ribot, Th. (1993). Filosofia lui Schopenhauer, traducere din limba franceză de Cornel Sterian, Editura Tehnică, București.

Rusu, L. (1969). Studiu introductiv, în Schopenhauer, 1969.

Safranski, R. (1998). Schopenhauer și anii sălbatici ai filozofiei. O Biografie, traducere din germană de Daniel Necșa, Editura Humanitas, București.

Schopenhauer, A. (1872). Aforisme pentru ințelepciunea in viață, Traducere de T. Maiorescu, în „Convorbiri Literare”, anul VI, nr. 8, Tipografia Societății Junimea, Iași.

Schopenhauer, A. (1876-1877). Aforisme pentru ințelepciunea in viață, traducere de T. Maiorescu, în „Convorbiri Literare”, anul X, nr. 1-12, Tipografia Societății Junimea, Iași.

Schopenhauer, A. (1890). Aforisme asupra înțelepciunii în viață, traducere de Titu Maiorescu, Editura Librăriei Socecu \& Comp., București.

Schopenhauer, A. (1912). Aforisme asupra înțelepciunii în viață, traducere de Titu Maiorescu, Editura Librăriei Socecu \& Comp., București.

Schopenhauer, A. (1969). Aforisme asupra înțelepciunii în viață, traducere de Titu Maiorescu, text stabilit de Domnica FilimonStoicescu, studiu introductiv de prof. univ. Liviu Rusu, Editura pentru Literatură Universală, București.

Schopenhauer, A. (1978).Gesammelte Briefe, A. Hübscher Verlag, Bonn.

Schopenhauer, A. (1997). Aforisme asupra înțelepciunii în viață, traducere de Titu Maiorescu, ediție îngrijită și postfață de Teodor Vârgolici, Editura Saeculum, Editura Vestala, București. 
Șăineanu, L. (1908). Dicționar universal al limbei române, a opta edițiune, revăzut și adăogit la Ediția VI-a, Editura „Scrisul românesc" S. A., [online].

Ungureanu, E. (2011). Textul și-textele, în: Parpală, E. \& Popescu, C. (eds.). Comunicare și identitate. Perspective lingvistice și culturale, Editura Universitaria, Craiova, p. 197-223, [online].

Vârgolici, T. (1997). Postfaţă la Schopenhauer, 1997. 